\title{
BELAJAR DAN PEMBELAJARAN BAHASA ARAB MADRASAH MINORITAS MUSLIM PAPUA BARAT
}

\author{
Ismail Suardi Wekke*, Muammar Nur** \\ *Sekolah Tinggi Agama Islam Negeri (STAIN) Sorong \\ **Universitas Islam Negeri (UIN) Maulana Malik Ibrahim Malang \\ Email: iswekke@gmail.com
}

\begin{abstract}
ABSTRAK
Bahasa Arab tak sekedar bahasa dalam memahami komunikasi antar manusia, melainkan juga alat komunikasi dengan Sang Pencipta. Kondisi bahasa Arab yang istimewa ini menjadi sebuah posisi yang perlu ditelusuri. Untuk itu, makalah ini akan menganalisis kondisi belajar dan pembelajaran bahasa Arab di minoritas muslim. Penelitian dilaksanakan di Papua Barat dengan subyek penelitian di madrasah Kabupaten Sorong. Pengumpulan data melalui wawancara dan pengamatan. Sepanjang tiga bulan mulai Februari sampai Mei 2016, pengumpulan data secara berkesinambungan. Makalah ini membahas dua aspek yaitu belajar dan pembelajaran. Dalam dinamika masyarakat minoritas muslim, bahasa Arab dicapai melalui dua hal tersebut. Secara formal pembelajaran berlangsung dengan konstruksi yang dilakukan secara kelembagaaan. Sementara di masyarakat juga berlangsung proses belajar yang dikreasikan secara informal dengan prakarsa dan inisiatif masing-masing keluarga secara tidak terstruktur. Akhirnya, kedua praktik berjalan seiring dan saling melengkapi untuk memberikan kesempatan bagi setiap warga muslim untuk belajar yang tidak terbatas pada kesempatan umur dan formalitas.
\end{abstract}

Kata kunci: belajar, pembelajaran, minoritas muslim

\section{PENDAHULUAN}

Terminologi pendidikan, berkembang menjadi pengajaran dan pembelajaran. Dalam kesatuan sistem pendidikan, pengajaran berada di pihak guru sementara siswa berposisi dalam proses pembelajaran. Masing-masing pengajaran dan pembelajaran menjadi unsur yang menjadi pilar untuk menyokong kelangsungan pendidikan. Perkembangan teknologi dan kemutakhiran komunikasi dan informasi menjadikan guru tidak lagi menanggung tugas seperti era sebelumnya. Bukannya makin mudah, justru muncul tantangan lebih besar sekaligus tidak dapat ditebak. Pada saat yang sama tantangan ini menjadi kesempatan untuk memberikan kesempatan kepada guru dalam melakukan inovasi. Dalam skala pendidikan Islam tetap saja ada harapan dan tantangan yang melingkupinya (Lubis \& Wekke, 2009). Sehingga pendidikan yang dijalankan 
akan memberikan makna bagi masing-masing peserta didik. Apapun pendekatan yang digunakan akan tetap efektif jikalau ditunjang oleh spirit belajar (Busse \& Krause, 2016). Guru tinggal memerlukan proses untuk menjelaskan konteks pembelajaran (Caro, Lenkeit, \& Kyriakides, 2016).

Dengan dua hal tersebut, maka guru harus sejak awal melengkapi diri untuk senantiasa berusaha mengadaptasikan diri menghadapi kemajuan. Tidak lagi dengan siklus tahunan, bahkan setiap detik lahir teknologi baru yang pada akhirnya akan berdampak kepada setiap individu. Pada gilirannya, ini juga akan memberikan pengaruh sampai ke ruang-ruang kelas. Untuk itu, sebuah proses yang berjalan secara simultan adalah kesempatan untuk melatih kemampuan psikomotorik (Daou, Lohse, \& Miller, 2016). Apalagi berkaitan dengan pembelajaran bahasa. Lingkungan menjadi sandaran utama belajar (Ke, Lee, \& Xu, 2016) dan budaya setempat menjadi salah satu acuan pembelajaran (Wekke, 2012), sehingga diperlukan refleksi guru untuk mengakselerasikan fokus pembelajaran (Mcalpine \& Pleschova, 2016). Makalah ini secara khusus mengidentifikasi belajar dan pembelajaran di madrasah minoritas muslim, Papua Barat.

\section{SISTEM PENDIDIKAN}

Bahasa menjadi keperluan dalam setiap interaksi. Ini berkaitan dengan penyampaian pesan. Menjadi sebuah kepentingan dalam mencapai pemahaman yang sama ketika menyampaikan sebuah bahasa dalam lingkungan tertentu. Untuk pembelajaran bahasa diperlukan sebuah upaya yang berbeda dengan pembelajaran materi lainnya. Dalam konteks ini, pendidikan dalam materi bahasa asing perlu dilihat dalam sistem pendidikan secara keseluruhan. Tidak saja sebagai sebuah materi pelajaran, lebih dari itu menjadi alat penguasaan keilmuan dalam perspektif yang luas. Mengkaji sumber-sumber yang berbeda, bahkan dalam beberapa cabang ilmu ada saja yang hanya bersumber dalam bahasa asing. Tanpa menguasai bahasa sumber maka akan timbul kesulitan dalam penguasaan ilmu tersebut. Termasuk pula tuntutan untuk publikasi antarbangsa yang mensyaratkan digunakan bahasa yang digunakan banyak kalangan. Diantaranya adalah bahasa resmi yang digunakan Perserikatan Bangsa-bangsa (PBB). Bahasa itulah yang perlu untuk dikuasai. 
Seolah-olah pendidikan hanyalah dilihat dari keriuhan sistem kurikulum yang dipersepsikan sebagai ganti menteri ganti kurikulum. Tetapi secara makro pendidikan sesungguhnya merupakan komponen yang sangat kompleks dan terintegrasi. Jikalau sebuah komponen tidak berjalan dengan baik akan mempengaruhi komponen yang lain. Guru yang memiliki dedikasi atas tugasnya. Tidak hanya diperlukan guru yang profesional ditambah dengan sertifikasi termasuk dengan tunjangannya. Ini bagian untuk kesejahteraan dalam menunjang tugas pokok. Hanya saja, dedikasi menjadi penyelesaian sebagian besar masalah. Pulau Arar di Kabupaten Sorong menemukan penyelesaikan dengan didirikannya sekolah menengah atas. Ini disponsori oleh Sekolah Tinggi Keguruan dan Ilmu Pendidikan Muhammadiyah Sorong. Dengan menggunakan aspek pengabdian masyarakat, penduduk yang mencapai 300 kepala keluarga dapat mengirimkan anak-anaknya untuk menempuh pendidikan di sekolah yang berada dalam pulau kecil itu. Guru-guru yang ditempatkan adalah mahasiswa yang masih duduk di semester akhir. Upaya ini menjadi efektif dan mengatasi ketiadaan sekolah. Akses pendidikan sudah bukan lagi masalah bagi penduduk Arar.

Pendidikan dalam lingkup yang kecil terutama di beberapa kawasan tertentu mengalami hambatan yang memerlukan perhatian. Tanah Papua dengan demografi wilayah pegunungan dan pantai. Ini menjadi tantangan tersendiri dalam penyebaran tenaga pengajar. Sebuah sekolah di Inawatan, Kabupaten Sorong Selatan hanya memiliki seorang guru. Sekaligus itu berfungsi sebagai kepala sekolah. Mengasuh enam kelas dan juga menyelesaikan seluruh administrasi pendidikan. Dengan tugas lainnya adalah pembersih, tenaga keamanan, dan juru kunci. Semua operasional sekolah dilaksanakan seorang diri dengan kompensasi gaji untuk satu pekerjaan saja. Ketika ada tugas yang diemban harus dilaksanakan di ibukota kabupaten, maka sekolah tidak mendapatkan pengasuhan guru lagi. Apalagi alat-alat komunikasi belum tersedia. Perjalanan dari Inawatan ke Teminabuan tidak dapat ditempuh dalam waktu sepekan untuk perjalanan pergi pulang. Jadwal kapal tidak tersedia setiap hari. Sehingga selama sepekan murid-murid tidak mendapatkan peluang untuk bertatap muka dengan guru. Tentu sudah dapat dipastikan bahwa sekolah ini tidak dapat menjadi sekolah yang ideal. Memberikan sarana bagi murid untuk mendapatkan inspirasi dari kelas menuju kehidupan yang nyata. 
Sementara fasilitas menjadi tantangan berikutnya. Sebuah sekolah di Makbon menempatkan buku-bukunya di ruangan kecil yang diperuntukkan menjadi kamar kecil. Karena ketiadaan ruangan, akibatnya buku-buku ditumpuk di ruangan itu. Tentu tidak dapat lagi digunakan dengan maksimal. Tidak ditempatkan di dalam rak kemudian disusun menurut tema tertentu yang akan menarik murid-murid untuk membacanya dan dipergunakan pula oleh murid yang lain sesudahnya. Justru, buku-buku itu mudah rusak dan tidak lagi dapat dibaca. Pilihan ini dilakukan karena ketiadaan ruangan lagi. Sementara untuk menempatkannya di kelas yang lain tidak tersedia lagi ruang. Pendanaan untuk buku itu menjadi sia-sia dan akhirnya berakhir menjadi tumpukan kertas yang dimakan rayap. Ketiadaan buku bacaan dan akses terhadap buku tambahan selain buku pelajaran hanya mengungkung murid-murid dalam satu bentuk pandangan saja.

Bukan berarti fasilitas adalah segalanya. Dengan keterbatasan fasilitas, Madrasah Aliyah Nurul Yaqin, Klalin dapat mengirimkan siswanya untuk belajar di tingkat perguruan tinggi. Beberapa universitas yang menerima lulusan madrasah tersebut antara lain Universitas Gadjah Mada, Yogyakarta, dan Insitut Pertanian Bogor. Di Kementerian Agama, Universitas Islam Negeri Sunan Gunung Djati, Bandung, dan Universitas Islam Negeri Sunan Kalijaga, Yogyakarta juga menerima alumni madrasah ini. Walaupun fasilitas yang serba terbatas dan bahkan tidak memiliki satupun laboratorium sebagai tambahan pelajaran untuk praktikum, penguasaan materi dan kemampuan menyelesaikan soal-soal ujian di tahapan akhir tetap saja mampu dilalui. Sehingga lulusan madrasah ini dapat bersaing dengan madrasah lain yang berasal dari wilayah yang memiliki fasilitas memadai. Sehingga pendidikan tidak dapat disandarkan hanya pada soal fasilitas tetapi juga berada pada kemampuan untuk menyerap materi pelajaran dan memecahkan masalah yang dihadapi. Ketidakmerataan fasilitas pendidikan merupakan sebuah problematika tetapi tidak boleh menjadi sebuah halangan bagi pengembangan pendidikan.

Tidak saja itu, dukungan dari lingkungan juga menjadi bagian yang membentuk kesamaan pandangan. Untuk membantu individu yang cemerlang, berkemampuan khusus, dan punya keinginan untuk melanjutkan pendidikan, tetapi tidak memiliki kemampuan dana untuk membiayai pendidikan, maka penduduk kampung berusaha bergotongroyong untuk memdanai bersama-sama siswa tersebut. Suku Ayamaru 
memiliki tradisi ini. Sehingga pejabat yang menduduki posisi tinggi biasa diisi oleh kalangan suku Ayamaru. Tradisi yang mereka kembangkan sudah berlangsung sejak lama. Bahkan ketika masih bernama Irian Jaya. Gubernur Irian Jaya Salosa berasal dari suku ini untuk menyebut sebagai contoh. Begitu juga dengan petinggi-petinggi dan pejabat senior di Kota Sorong seperti walikota Jumame, dan Lamberthus Jitmau. Keduanya juga berasal dari suku Ayamaru. Ketika pendanaan pemerintah melalui program Bantuan Operasional Sekolah (BOS) dijalankan, suku Ayamaru telah melakukan ini secara komunal. Sehingga dapat mendorong warga mereka menempuh pendidikan sampai ke tingkat lanjut. Sementara ketika orang yang dibantu secara tersebut sudah menduduki posisi tertentu, secara aktif dia berusaha mengembangkan masyarakat dan mengembalikan baktinya kepada masyarakat dalam bentuk turut mendanai putra-putri terbaik untuk melanjutkan pendidikan juga. Keterbatasan disiasati secara bersama-sama, bukan dengan sekedar hanya melihat masalah yang ada. Tetapi berusaha untuk menemukan solusi bagaimana masalah itu dapat terpecahkan. Ketiadaan dana bukanlah halangan, justru hal yang paling diperlukan adalah keinginan untuk mendalami ilmu pengetahuan sebagai modal yang paling penting.

Pola yang digunakan suku Ayamaru secara adat ini diadaptasi menjadi pertauran komunitas di Kabupaten Sorong. Dengan difasilitasi oleh Pemerintah Kabupaten diundangkan dalam bentuk peraturan kabupaten sebagaimana usulan setiap suku untuk mengadakan kesepakatan. Salah satu butir kesepakatan itu adalah dukungan bersama bagi pendidikan formal. Anak-anak yang memiliki kemauan dan kemampuan untuk menempuh pendidikan senantiasa didorong dan diberikan kesempatan menjalaninya. Bahkan sampai pendidikan tertinggi. Ketika diantara mereka menemukan kesulitan pendanaan, maka ini menjadi tanggung jawab komunitas untuk memenuhi kebutuhannya. Sehingga praktik baik yang sudah dicontohkan suku Ayamaru kemudian diadaptasi ke dalam pelbagai suku. Sehingga tidak ada lagi anak-anak yang putus sekolah karena alasan pendanaan.

Potret yang lain patut untuk dijadikan inspirasi, sebuah madrasah di Kota Malang dengan nama Madrasah Ibtidaiyah Negeri Malang 1. Madrasah ini merupakan sekolah yang mencapai prestasi nasional bahkan dalam beberapa kesempatan menjangkau taraf internasional. Salah satu rahasia kecil di madrasah ini adalah kesediaan guru untuk mengidentifikasi dan membangun keakraban dengan murid-muridnya. Kepala madrasah 
menjadi orang yang pertama datang dan menyalami semua murid sebelum masuk ke dalam kelas. Setelah itu, dilakukan tadarus sebelum dimulai proses belajar selama 15 (lima belas) menit perhari. Sebelum pulang, kembali kepala madrasah akan berdiri di depan kompleks madrasah menyalami sekali lagi murid-murid yang akan pulang ke rumah. Sebuah langkah yang sangat biasa dan memberikan dampak besar bagi perkembangan madrasah. Madrasah menjadi sarana untuk membentuk perilaku yang dilandasi atas semangat salam. Justru dengan salam ini, kepemimpinan kepala sekolah terlihat nyata. Sehingga separuh masalah sudah terselesaikan.

Dengan melakukan aksi yang kecil seperti ini, guru-guru datang dan pulang sesuai dengan jadwal. Mereka akan memiliki rasa malu kalau datang terlambat karena pemimpinnya sudah berada di madrasah sebelum waktu pelajaran. Sementara itu, pemimpin juga pulang setelah proses belajar usai dilaksanakan. Sekaligus aksi kejahatan berupa penculikan murid-murid sudah terhindarkan karena mereka diketahui siapa yang menjemput. Dalam pendidikan tidaklah hanya tentang ide-ide besar dan prestasi yang megah. Tetapi ada kesempatan-kesempatan tertentu untuk memunculkan sebuah hal kecil yang justru berdampak secara luas. Pendidikan menjadi sarana untuk melalukan sebuah karya nyata dan pengabdian. Ketika ini berjalan, maka Yang Kuasa justru menunjukkan bagaimana dapat berdampak dan menjadi kerja besar yang membantu khalayak.

Salah satu kunci keberlangsungan pendidikan sehingga bisa bertahan dengan segala kekurangan yang ada adalah pengabdian. Seorang guru dengan status sukarela tidak mendapatkan gaji sama sekali. Selama dua belas tahun mengajar di madrasah ibtidaiyah. Tidak ada kontrak ataupun surat keputusan dari pejabat yang berwenang sebagai pegangan. Pada tahun ketigabelas mendapatkan pengangkatan setelah menyelesaikan sekolah pendidikan guru. Bersama dengan satu orang rekannya yang juga mulai mengabdi pada tahun yang sama. Setelah itu, tiga puluh tahun berikutnya mengabdi dengan sepenuh hati. Saat mencapai usia pensiun memilih berhenti saat itu juga. Walaupun masih diminta untuk memperpanjang masa pengabdian beberapa tahun lagi sampai didapatkan kepala sekolah pengganti yang mampu berkomitmen untuk turut menjaga kelanjutan program pendidikan. Sekolah ini berada di tempat terpencil sehingga terkadang hanya dua guru yang ada untuk mengajar enam kelas. Setelah pensiun, masih saja berkontribusi. Memberi pandangan pada penyelenggaraan 
pendidikan secara umum. Tidak mau turut campur secara teknis dalam pendidikan tetapi berusaha membantu atas kesulitan yang dihadapi. Ketika sekolah memerlukan rumah bagi penginapan guru, maka dilandasi keinginan melihat keberadaan sekolah, meminta saudara tuanya untuk mewaqafkan tanahnya kepada pemerintah.

Ini menjadi gambaran bagaimana pendidikan dijaga hanya karena pengabdian seorang guru. Sepanjang hidupnya digunakan untuk memikirkan bagaimana pendidikan dapat terus menjadi sarana bagi pencerahan masyarakat. Tidak untuk apa-apa kecuali karena semua yang belajar adalah keluarganya sendiri. Satu desa merupakan keluarga besar, berasal dari keturunan yang sama. Desa terlayani dengan keinginan dan citacitanya yang melihat pendidikan sebagai satu-satunya jalan kehidupan. Walaupun dengan keterbatasan kehadiran guru karena daerah yang terpencil, anak-anak punya kemauan belajar dengan semangat yang tinggi. Mereka kemudian berusaha melanjutkan pendidikan sampai ke jenjang pendidikan tinggi. Walaupun pendidikan menengah harus ditempuh di luar desa. Tinggal di rumah kerabat atau mukim di asrama sekolah. Beberapa diantara mereka bahkan sudah mencapai gelar tertinggi dalam pendidikan. Selanjutnya, menempati posisi yang strategis dalam pemerintahan. Turut berkontribusi memikirkan bagaimana pengembangan masyarakat.

Pemerolehan bahasa memerlukan sistem panca indra secara kompleks. Termasuk keterlibatan emosi di dalamnya. Sekumpulan anak muda dari Papua Barat melakukan perjalanan ke luar negeri dengan menelusuri Hong Kong, Shenzhen, Macau, Kuala Lumpur, dan Singapura akan mendapatkan pengertian yang seksama bagaimana sebuah perjalanan direncanakan dan juga diselesaikan. Pengalaman berjalan dan berpetualang tidaklah akan sama derajat pemahamannya jikalau hanya dilakukan dengan membaca ataupun menonton film. Ketika dalam perjalanan, ini berkaitan dengan pengeluaran dan juga mendapatkan pendanaan. Sebuah kegairahan dan juga kadang kekesalan sebagai dampak dalam menjalani kegiatan yang sudah direncanakan. Begitu pula dengan harapan yang tidak sesuai atau juga ada hal yang didapatkan melambung tinggi dan justru tidak pernah terbayang sebelumnya. Pada saat perjalanan berlangsung ada-ada saja masalah yang dihadapi. Semuanya berusaha untuk dipecahkan. Tidak ada perjalanan yang menyenangkan kalau saja itu berhenti di tengah jalan dan tidak bisa pulang ke rumah. Bahkan bisa saja muncul istilah tersesat. Sebaik-baik perjalanan adalah rangkaian yang diakhiri dengan pulang. Ini melibatkan emosi dengan sepenuh 
jiwa dan raga. Pengalaman seperti ini akan memberikan perspektif, pandangan, dan juga sebuah pengalaman sepanjang umurnya.

Sebuah pendidikan akan seperti itu juga. Perjalanan yang ditempuh dengan memberikan kesempatan bagi peserta didik untuk mendapatkan sebuah pengalaman yang akan memberikan dampak bagi kehidupannya. Sebuah kesempatan dengan program terstruktur. Sekaligus sebagai sebuah upaya dalam memperoleh banyak informasi, melatih, kemudian berada pada tingkatan penguasaan. Semua keterampilan ini akan digunakan dalam sisa umur hidupnya secara produktif. Tidaklah akan berguna sama sekali kalau pengalaman belajar yang didapatkan tidaklah kontekstual dan berhubungan dengan kehidupan yang dialami dalam lingkungan masing-masing peserta didik. Kondisi seperti ini yang perlu untuk dikreasikan seorang guru sebagaimana illustrasi perjalanan ke luar negeri. Dalam beberapa kegiatan dihubungkan oleh sebuah benang merah yaitu bagaimana belajar akan memberikan pandangan dan informasi yang dapat digunakan. Tidak sekadar maklumat tetapi merupakan kebutuhan yang diperlukan sebagaimana dalam menikmati perjalanan sehingga tujuan akhir yaitu pulang dapat tercapai.

\section{BELAJAR DAN PEMBELAJARAN}

Dua pihak yang berbeda tetapi berada dalam satu proses, hanya sisi saja yang berbeda adalah guru dan siswa. Keduanya menjalankan satu keadaan yang sama, hanya saja mereka memiliki peran yang berbeda. Dengan tugas yang diembannya masingmasing pihak jika dilaksanakan dengan kesadaran, akan pengalaman yang justru memberikan perubahan dalam kerangka sistem. Guru dan siswa mengembangkan interaksi yang sama dan mencapai hasil yang berbeda. Ketika guru menjalankan tugasnya, maka arah pendidikan akan tertata. Sementara siswa yang berusaha untuk menuruti program yang dijalankan gurunya, akan mencapai hasil belajar yang diinginkan. Jikalau antara guru dan siswa saling membangun kepercayaan, maka pendidikan bangsa akan mendapatkan sumber-sumber kemajuan. Dalam pembelajaran, guru bertugas merencanakan pembelajaran sampai pada memberikan pengaruh bagi siswa dalam bentuk perubahan perilaku. Sementara siswa dengan mengikuti arahan dan panduan yang sudah direncanakan, akan menjadikan proses yang dilaluinya sebagai makna yang dihubungkan dalam kehidupan sehari-hari. 
Dalam belajar, perubahan tingkah laku akan menjadi indikator utama bagaimana keberhasilan belajar itu dapat dicapai. Sebuah pemahaman tidak dapat diukur dan diketahui pihak lain. Sehingga sebuah proses belajar akan menemukan konteksnya jikalau apa yang sudah diketahui itu dapat ditunjukkan dalam bentuk karya nyata. Wujud belajar ditunjukkan dalam bentuk indikator atau tanda yang diketahui pihak lain. Sebuah kemampuan tidak hanya dalam bentuk proses berpikir. Tetapi harus melampaui jauh dari itu sampai kepada kemampuan yang lahir dari pergulatan pikiran yang ada.

Dukungan penyediaan sarana pembelajaran dapat dibentuk dengan ketulusan. Kiyai Yasin di Aimas, Pengasuh Pondok Pesantren Roudhotul khuffadz. Beliau mulai mengembangkan pesantrennya dimulai dari pengajian dan panti asuhan. Kesungguhannya mengasuh dan membina santri salah satunya dalam bentuk keteladan sehingga masyarakat memberikan kepercayaan untuk menyekolahkan putra-putrinya di lembaga itu. Sekarang ini, madrasah Roudhotul Khuffadz sudah terbentuk madrasah tsanawiyah. Madrasah Ibtidaiyah yang dibangunnya sudah menamatkan siswa sehingga kelanjutan dalam bentuk sekolah menengah dibangun. Lahan sekolah sudah mencapai 10 (sepuluh) hektar. Awalnya hanya dalam bentuk satu lahan untuk membangun rumah yang ditinggalinya. Sekaligus pula digunakan sebagai asrama untuk santri. Bersama dengan istrinya yang mengasuh santriwati. Mereka hidup dengan kehidupan yang sederhana ala pesantren. Mengelola kepercayaan umat dengan memberikan kesempatan terbaik bagi santri dan santriwati untuk belajar agama sekaligus mempraktikannya di lingkungan pondok.

Bahkan, santri dan santriwati masih di bangku ibtidaiyah sudah diasramakan. Mereka berpisah dengan orang tua, hidup di pesantren. ketika di pesantren dalam umur 7 (tujuh) tahun itu mereka sudah hidup mandiri. Bisa mengatur barang-barang yang dimiliki. Kemudian mengikuti kegiatan yang sudah dijadwalkan oleh pengelola pondok. Waktu bermain yang terjadwal. Tidak ada kegiatan menonton televisi. Tidak memiliki waktu untuk bermanja-manja. Ini karena sistem pendidikan yang sudah diatur dan dilaksanakan secara konsisten. Orang tua sudah sejak awal bahkan pada tingkatan madrasah ibtidaiyahpun sudah merelakan anak-anaknya dibimbing oleh Kiyai Yasin. Sumber pendapatan utama pondok berasal dari pertanian, perikanan, dan peternakan yang dikelola para pengasuh. Sepenuhnya digunakan untuk kepentingan pondok. 
Perkembangan terakhir, pengasuh pondok mulai mengembangkan bisnis ikan hias. Dana stimulus diperoleh dari bantuan pemerintah melalui dinas dan kementerian.

Keterbatasan sarana pembelajaran justru menjadi tantangan tersendiri. Ketika pemerintah belum menjangkau wilayah tertentu di Papua, ada saja sosok dari tokoh masyarakat yang mau bekerja dan menginvestasikan waktu dan tenaga untuk kepentingan orang banyak. Dengan tidak menjadikan ego dirinya sendiri sebagai tujuan hidup, kelompok-kelompok masyarakat kemudian bersama-sama untuk menyediakan fasilitas. Ini semua terutama untuk kalangan masyarakat sekitar. Adapun bagi masyarakat yang jauh, kesempatan ini terbuka secara luas. Mereka dapat mengirimkan putra-putrinya untuk turut belajar. Bahkan disediakan bantuan pendanaan melalui lembaga panti asuhan. Sehingga masyarakat muslim terlayani dalam kebutuhan pendidikan agama.

\section{PEMBELAJARAN BAHASA MODERN}

Penguasaan bahasa tidak lagi sebatas pada bahasa ibu saja. Melampaui itu semua, diperlukan penguasaan bahasa asing sebagai dasar untuk memahami gagasan dari bangsa lain. Untuk kepentingan hubungan antar bangsa itu, maka penelitian yang berkelanjutan terus dilakukan untuk menjadi inovasi dan praktik cerdas bagi program yang sama di tempat yang lain. Sebaliknya, sebuah program yang berhasil di tempat tertentu tidak dapat dipindahkan ke tempat lain begitu saja. Betapa hasil yang ditunjukkan pesantren Darussalam di Gontor Ponorogo ketika diadopsi dan diadaptasi ke pesantren lain tidak mencapai keberhasilan seperti yang didapatkan oleh pesantren Darussalam. Ini karena ada faktor lain yang tidak berhubungan dengan pembelajaran tetapi justru menjadi bagian vital dari proses pembelajaran yang dilaksanakan.

Madrasah Tsanawiyah Pesantren Roudhotul Huffadz, Aimas dan Madrasah Aliyah Pesantren Nurul Yaqin, Klain. Kedua pesantren tersebut berusaha untuk mengadaptasi pendidikan bahasa modern untuk dijadikan sebagai landasan bagi pengembangan pembelajaran bahasa di masing-masing madrasah. Dengan arah yang sama, tetapi capaian yang diperoleh justru mendapatkan hasil yang sangat berbeda jauh. Madrasah Tsanawiyah Pesantren Roudhotul Huffadz dapat memberikan transfer keterampilan dalam penguasaan kosa kata. Sementara Madrasah Aliyah Pesantren Nurul Yaqin justru kemudian mengalami kesulitan dalam menerapkan madrasah diniyah yang 
dijadikan sebagai kesatuan yang sama dengan program kepesantrenan. Hanya saja dengan pembelajaran bahasa modern, kedua pesantren tersebut dapat mencapai keterampilan berbahasa yang lebih baik daripada target kurikulum madrasah. Sehingga dengan pelbagai perbaikan dan juga kesinambungan program tersebut tetap dijalankan untuk menjadi bagian dari program-program madrasah.

Guru yang menguasai keterampilan belajar mengajar dengan pelatihan untuk mengajar bahasa secara komunikatif menjadi bagian penting. Termasuk kemampuan untuk beradaptasi dan berasimilasi dengan lingkungan yang ada di madrasah-madrasah Papua. Beberapa madrasah setelah mendapatkan bantuan tenaga pengajar dari pondok di Pulau Jawa sangat terbantu. Hanya saja, beberapa di antara mereka hanya mampu untuk mengajar selama dua bulan. Bukan karena penguasaan materi dan keterampilan mengajar yang minim. Sekali lagi, bukan semua itu. Tetapi kondisi lingkungan di Papua yang menantang tidak dapat mereka taklukkan. Padahal mereka berada di madrasah yang relatif maju seperti di Aimas. Bukan di daerah yang berada di pedalaman ataupun area pantai yang jauh dari pusat-pusat aktivitas utama.

Di madrasah Indonesia, sistem pembelajaran bahasa dengan menggunakan pola modern dimulai ketika Gontor didirikan. Saat itu diperlukan utusan dari Indonesia untuk mewakili di forum internasional. Hanya saja, persyaratan keikutsertaan adalah individu yang menguasai bahasa Arab dan Inggris sekaligus secara aktif untuk kepentingan komunikasi. Tetapi tidak didapatkan satu orang yang menguasai dua bahasa itu. Akhirnya, diputuskan untuk mengirimkan dua orang. Satu orang menguasai bahasa Inggris. Sementara satu orang lagi hanya menguasai bahasa Arab. Dari peristiwa yang sederhana ini, akhirnya menjadi inspirasi bagi Tri Murti untuk mendirikan Kulliyah Muallimin Islamiyah (KMI). Sebuah madrasah yang secara khusus berusaha untuk memberikan pembelajaran bahasa Arab secara moderen. Dilakukan dengan pola sekolah dengan materi pelajaran bahasa Arab sebagai pengantar ilmu agama. Ini juga menjadi sebuah latihan bagi tersedianya guru-guru agama yang memiliki keterampilan berbahasa secara aktif.

Bukan juga berarti bahwa dengan hanya menumpukan pendidikan bahasa pada kemampuan berkomunikasi kemudian menghilangkan aktifitas dalam membaca dan menerjemahkan. Membaca kitab tsurats atau yang dikenal dengan istilah kitab kuning tetap perlu dilakukan. Program ini perlu dilakukan terutama untuk siswa tingkat lanjut. 
Terutama bagi yang sudah menguasai keterampilan berkomunikasi. Bagi yang akan menekuni kajian keagamaan, penguasaan membaca kitab-kitab tersebut menjadi salah satu prasyarat sehingga pemahaman sumber-sumber keagamaan lebih komprehensif. Selanjutnya perlu digabungkan dengan jurnal-jurnal bereputasi dan penelitian terkini dari pusat-pusat penelitian keislaman yang ada di Eropa dan Amerika. Dalam menggembleng kemampuan ini, beberapa madrasah melaksanakannya dalam bentuk madrasah diniyah. Ada pula yang memberi istilah pendidikan kader ulama. Program takhashshush menjadi nama yang lain.

Pembelajaran bahasa di madrasah menempatkan bahasa Arab sebagai pelajaran utama. Keberadaan bahasa Arab terutama berkaitan dengan mata pelajaran lain yang juga menggunakan bahasa Arab sebagai bagian dari pemahaman materi pelajaran. Seperti al-Quran dan Hadis, keduanya menjadikan pendekatan kebahasaan sebagai salah satu praktik pengkajian untuk memahami kandungan keduanya. Selanjutnya, sumbersumber materi seperti Sejarah Kebudayaan Islam, Aqidah Akhlak, Fikih, juga semuanya memerlukan interaksi dengan bahasa Arab. Walaupun tidak berada dalam posisi sebagai bagian pembahasan. Hanya saja, keterampilan dan pemahaman kebahasaan akan membantu penguasaan materi mata pelajaran tersebut.

Pesantren menjadi salah satu contoh bagaimana pembelajaran bahasa Arab dapat berlangsung. Kehadiran kiyai merupakan sebuah potret dimana kelembagaan pesantren dapat menjadi pionir, terutama maksud awal pendirian adalah menjadi lembaga tafaqquh fi al-din (pendidikan kader ulama). Tidak sampai di situ saja, pesantren kemudian menjadi sebuah alat bagi membangun segala aspek kehidupan. Mulai terlibat dalam urusan pertanian, peternakan, dan juga pengembangan teknologi. Melalui madrasah, pesantren memberikan kesempatan untuk mengikuti pendidikan formal. Setelahnya, keterampilan yang berhubungan dengan konteks masing-masing masyarakat menjadi perhatian. Di Klain, Madrasah Nurul Yaqin mengembangkan kemampuan pertanian, dan perikanan. Sementara Madrasah Roudhutul Khuffadz, Aimas mengembangkan pertanian, perikanan, dan peternakan. Untuk pertanian, masing-masing kedua madrasah tersebut menanam tanaman jangka pendek berupa palawija yang dapat dipetik dalam musim tanam tidak lebih dari empat bulan. Dengan pertanian ini bukan semata-mata untuk membantu keuangan madrasah tetapi juga sebagai sarana dalam 
melatih keterampilan santri. Dalam hal perikanan selain pemeliharaan ikan air tawar juga mengembangbiakkan ikan hias.

Pilihan-pilihan implementasi program seperti itu dilaksanakan supaya menarik minat siswa. Jikalau hanya diajarkan dalam bentuk formal di ruang kelas, maka proses interaktif tidak akan didapatkan. Perilaku tidak hanya dipelajari semata-mata di ruang kelas. Ini dapat juga diperoleh melalui praktik secara langsung. Dengan pengalaman, kompleksitas pembelajaran langsung dipahami sekaligus akan menumbuhkan adaptasi. Pembelajaran melibatkan juga panduan dari instruktur dalam skala terkecil sekalipun. Sehingga kalau tidak diberikan bimbingan, maka perilaku yang terbentuk tidak dapat memperoleh penjelasan yang memadai sehinga dapat saja merupakan proses trial and error.

Bentuk pembelajaran seperti ini merupakan lingkungan yang dimodifikasi sebagai sarana belajar. Tidak saja dalam bentuk yang natural atau alami. Tetapi dengan program yang terencana dan terstuktur, akan menjadikan proses pembelajaran yang lebih variatif. Tidak berlangsung sebagaimana adanya yang kadangkala tidak dapat memenuhi keinginan dalam implementasi program kurikulum. Sebuah pertentangan wacana bagaimana pembelajaran dalam laboratorium dengan suasana natural. Proses alami berlangsung dalam suasana yang tidak memberikan kesempatan kepada siswa untuk mengadakan interaksi dengan apa yang dipelajari. Semata-mata hanya mendengarkan dan mempelajari pengalaman yang didapatkan gurunya. Sementara dengan terjun secara langsung dalam praktik maupun di laboratorium, siswa akan mendapatkan pengalaman dengan bimbingan gurunya. Ketika memerlukan klarifikasi ataupun penjelasan lebih detail, maka guru selalu berada di sampingnya untuk menjadi fasilitator pembelajaran.

Kesempatan siswa untuk belajar otodidak semakin terbuka dengan kesempatan yang lebih luas. Seorang mahasiswa yang belajar di kota Yogyakarta dengan kegemarannya terhadap sinteron Korea sehingga setiap hari menyempatkan diri untuk menonton sinetron dan film Korea. Baik itu melalui televisi kabel maupun dengan menyewa piringan cakram (CD) maupun dengan mengunduh filenya melalui internet. Walaupun tidak terprogram tetapi dilaksanakan dengan rutin, akhirnya mahasiswa ini menguasai bahasa Korea. Paling tidak istilah dan dialog percakapan yang berlangsung di film dan sinetron dapat dipahaminya. Dalam contoh ini, ternyata belajar bahasa tidak hanya dapat dilakukan di dalam kelas saja. Dengan inisiatif dan dibarengi dengan minat, 
maka akhirnya menguasai bahasa tidaklah serumit yang dibayangkan. Bahkan dengan tetap santai dan tidak mengalami perasaan tertekan, belajar bahasa justru menjadi kegiatan yang menyenangkan.

Sebuah contoh lain dalam konteks yang sama. Seorang mahasiswi di Kota Sorong. Gemar mendengarkan lagu-lagu India. Dalam fase selanjutnya, tidak saja kegemarannya ini menuntun untuk menjadi konsumen lagu-lagu tersebut. Tetapi secara perlahan mulai juga belajar bahasa India. Melalui lagu, bahasa yang dipelajari dimulai dari aspek komunikasi. Walaupun berawal dari bentuk sastra berbentuk lagu, akhirnya mengantar untuk menekuni sastra India dengan kemampuan tingkat tinggi. Sehingga pada satu kesempatan tertentu, dalam menonton film India tidak lagi memerlukan penerjemahan. Sebuah keterampilan yang dibangun sejak awal hanya karena senang lagu-lagu india.

Kedua contoh ini dapat dijadikan dasar bahwa sesungguhnya belajar bahasa dapat menyesuaikan dengan perangkat terkini. Tidak semata-mata bahwa belajar bahasa harus duduk di dalam kelas dan kemudian mendengarkan materi yang disampaikan guru. Era teknologi menjadikan abad ini sebagai abad informasi. Dengan segala kecanggihan yang mengiringinya akan sangat membantu dalam menguasai bahasa. Ada kemudahankemudahan yang tersedia bahkan itupun dengan tanpa biaya sama sekali. Kesempatan ini membuka cakrwala dan juga kesempatan yang lebih luas. Pada akhirnya kita tidak dapat menghindari kemajuan teknologi ini. Tetapi justru menjadi sebuah kesempatan untuk menjadikannya sebagai bagian dari inovasi.

Pembelajaran di madrasah minoritas muslim mencerminkan sebuah adaptasi terhadap lingkungan. Mulai dari rekonstruksi kurikulum (Wekke, 2014) hingga pada inovasi pembelajaran (Wekke, 2016). Keadaan ini berawal dari prakarsa untuk memberdayakan lingkungan (Wekke, 2013). Kondisi ini kemudian memberikan kesempatan kepada para guru untuk senantiasa melakukan prakarsa dan inisiasi sehingga pembelajaran bahasa Arab dapat dikembangkan. Termasuk adanya usaha untuk mengintegrasikan pelbagai pendekatan pembelajaran (Wekke,2015). Proses yang terjadi tidak bisa serta-merta, diperlukan proses yang berkesinambungan sehingga didapatkan hasil sesuai dengan harapan. Evolusi pembelajaran menuntut adanya program yang terencana dan dilaksanakan secara berkelanjutan (Wesner, Pierce, Slater, \& Johnson, 2016). 
Temuan penelitian ini menunjukkan bahwa dengan adanya program yang ditentukan akan lebih mudah mewujudkan pembelajaran. Termasuk dengan mengupayakan adanya contoh dan teladan (Shafto, Goodman, \& Griffiths, 2014). Demikian pula dengan keterlibatan tidak hanya ketika pedagogi berlangsung di dalam kelas saja tetapi diperlukan pula interaksi usai jam pelajaran (Scolaro, Carrington, \& Ferreri, 2016). Begitu juga dengan kemampuan guru untuk selalu mengintegrasikan pelbagai keadaan dan memastikan bahwa ada beberapa teknik yang dapat digunakan secara bergantian (Ke et al., 2016). Maka, pembelajaran di madrasah minoritas muslim senantiasa memerlukan integrasi pembelajaran, tidak saja berkaitan dengan lingkungan sekolah dalam arti yang terbatas tetapi juga mencakup lingkungan secara luas dimana adanya interaksi dengan masyarakat sebagai bagian yang tidak terpisahkan.

\section{PENUTUP}

Akhirnya, dalam kaitan dengan inovasi ini maka tentu diperlukan kreativitas sebagai mantra untuk menjadikan sinergitas antara keperluan dengan kemajuan teknologi. Sebuah mesin anjungan tunai mandiri (ATM) bank yang beroperasi di bagian selatan China, kota Shenzhen. Ketika seorang nasabah menunggu untuk pengambilan uang, maka mesin itu kemudian justru tidak saja menayangkan informasi saldo yang tersedia. Tetapi juga menayangkan kalimat-kalimat motivasi yang dikutip dari sastrawan. Pada saat itu, nasabah menarik uang sebanyak dua kali. Dalam dua kesempatan itu justru kalimat motivasi yang disampiakan juga adalah kalimat yang berbeda. Ini menjadi sebuah contoh bagaimana institusi perbankan tidak saja menjadi bagian dari sistem keuangan tetapi berusaha melampaui tugasnya yang utama. Lembaga perbankan hanyalah perusahaan yang menjalankan usaha di bidang keuangan untuk mencapai keuntungan maksimal. Hanya saja, dalam usaha itu tidaklah melupakan untuk memberikan pencerahan bagi nasabahnya. Langkah seperti ini justru bukan merobohkan usaha utamanya. Justru akan memberikan kenyamanan dan kelapangan kepada nasabahnya. Sehingga dengan dukungan penuh nasabah dan sekaligus menjadi tenaga pemasaran yang handal dan tidak perlu dibayar oleh perusahaan, mereka akan semakin loyal dan menjadi pelanggan setia.

Kecenderungan terus berjalan seiring dengan perubahan keperluan masing-masing masyarakat. Perhatian terhadap metode tidak lagi bertumpu secara khusus dalam kaitan 
dengan ini. Perhatian juga mulai tertuju kepada rancang bangun kurikulum atau silabus. Demikian pula dalam hal tujuan pengajaran bahasa. Pembelajaran bahasa juga sudah mulai berkaitan dengan aspek linguistik terapan lainnya. Sehingga dengan kecenderungan yang terus bergulir seperti ini menjadi suatu keperluan kepada setiap pengajar untuk mulai mengadaptasikan perkembangan yang ada untuk diakselerasikan dengan kelas yang diasuhnya. Kebutuhan terus berubah, maka kelaspun harus berubah sesuai dengan kebutuhan riil yang wujud saat itu.

\section{DAFTAR PUSTAKA}

Busse, V., \& Krause, U. (2016). Instructional methods and languages in class: A comparison of two teaching approaches and two teaching languages in the fi eld of intercultural learning. Learning and Instruction, 42, 83-94.

Caro, D. H., Lenkeit, J., \& Kyriakides, L. (2016). Teaching strategies and differential effectiveness across learning contexts: Evidence from PISA 2012. Studies in Educational Evaluation, 49, 30-41.

Daou, M., Lohse, K. R., \& Miller, M. W. (2016). Human Movement Science Expecting to teach enhances motor learning and information processing during practice. Human Movement Science, 49, 336-345.

Ke, F., Lee, S., \& Xu, X. (2016). Teaching training in a mixed-reality integrated learning environment. Computers in Human Behavior, 62, 212-220.

Lubis, M. A. \& Wekke, I. S. (2009). Integrated Islamic education in Brunei Darussalam: The hopes and challenges. EDUCARE: International Journal for Educational Studies, 1(2) February, 141-156.

Mcalpine, L., \& Pleschova, G. (2016). Helping teachers to focus on learning and reflect on their teaching: What role does teaching context play? Studies in Educational Evaluation, 48(May 2008), 1-9.

Scolaro, K. L., Carrington, J. L., \& Ferreri, S. P. (2016). Involvement in teaching after completion of a teaching and learning curriculum. Currents in Pharmacy Teaching and Learning, 8(4), 524-530.

Shafto, P., Goodman, N. D., \& Griffiths, T. L. (2014). A rational account of pedagogical reasoning: Teaching by, and learning from, examples. Cognitive Psychology, 71, 55-89.

Wekke, I. S. \& Andriansyah. (2016). From Gontor to Sorong: Muslim minority practices on arabic teaching and learning. SOSIOHUMANIKA: Jurnal Pendidikan Sains Sosial dan Kemanusiaan, 9(1) May, 49-54.

Wekke, I. S. (2012). Amalan pengajaran dan pembelajaran Bahasa Arab di Pesantren Immim Makassar, Indonesia. Disertasi. Bangi; Fakulti Pendidikan, Universiti Kebangsaan Malaysia.

Wekke, I. S. (2013). Religious education and empowerment: study on pesantren in muslim minority West Papua. Miqot: Jurnal Ilmu-Imu Keislaman, 37(2), 374-395.

Wekke, I. S. (2014). Tradisi pesantren dalam konstruksi kurikulum bahasa Arab di lembaga pendidikan minoritas muslim Papua Barat. Jurnal Karsa, 22(1), Juni, 2139. 
Wekke, I. S. (2015). Antara Tradisionalisme dan Kemodernan: Pembelajaran Bahasa Arab Madrasah Minoritas Muslim Papua Barat. Jurnal Peradaban Islam Tsaqafah, 11(2), November 2015, 313-332.

Wesner, A. R., Pierce, R., Slater, N., \& Johnson, M. (2016). Evolution of a regional pharmacy residency teaching and learning curriculum program. Currents in Pharmacy Teaching and Learning, 8(4), 469-476. 